This is the 'accepted' manuscript of:

Hussein, S. \& Oglak, S. (2013) Training unemployed women for adult day care in Izmir, Turkey: A Program Evaluation, Gerontology \& Geriatrics Education, iFirst 3 Apr 2013. DIO: 10.1080/02701960.2013.790819.

\title{
Training unemployed women for adult day care in Izmir, Turkey: A Program Evaluation
}

\section{Shereen Hussein}

School of Social Science and Public Policy,

King's College London,

London, UK

\section{Sema Oglak}

Vocational School of Health Care,

Dokuz Eylul University, I

zmir, Turkey

Corresponding author: Dr Shereen Hussein; Shereen.hussein@kcl.ac.uk

\begin{abstract}
The proportion of older people in Turkey is increasing steadily with a subsequent growth of long-term care (LTC) needs. There is a scarcity of formal care provision, for residential and particularly non-residential settings. Thus, formal caregiving is not meeting LTC needs nor attracting workers as a labor option. We examine the hypothesis that LTC may offer work opportunities for women unfamiliar with caregiving as an occupation, we also examine the need and acceptance of different types of LTC beyond residential care. We evaluate an innovative project introducing these two elements to 76 women in Izmir, Turkey, using an analysis framework that incorporates factors related to applications and progression; management assessment, trainees' self-assessment reflecting on their views on aging; and older people's perception of the experience and its impact on their wellbeing. Trainees reported a major positive shift in their attitudes toward working in LTC and toward the aging process. Users reported discovering a new dimension in care, which directly impacted their quality of life. Overall, this community-based initiative appeared effective in enhancing the awareness of the concept of adult day centers providing a social model of care and appears promising in addressing the growing needs of formal LTC in Turkey.
\end{abstract}

Keywords: program evaluation, Turkey, long-term care, unemployment, labor market activation, older people, adult day care 


\section{Introduction}

This study addresses the growing needs of formal long-term care in Turkey and the corresponding escalating demands for formal caregivers. It introduces the process and initial evaluation of an innovative project, Educating Caregivers for Employment in Adult Day Care Centres in Izmir (SBAP), which tackles two pressing policy concerns in Turkey. The first is to introduce a new form of care services that meets the growing demand for long-term care in a culturally sensitive way while maintaining the integration of older people within the community through the introduction of adult day care (ADC) service as a substitute and complement to the existing but limited institutional care services in the region. The second policy concern relates to a shortage of well-trained formal caregivers to meet the growing needs of long-term care. The project offered an opportunity to develop skills and training capacity to work in the formal caregiving sector.

\section{Context of aging policy in Turkey}

In Turkey as in most of the globe, the numbers and proportions of older people are steadily increasing with direct implications on the demand for long-term care. These changes are occurring in parallel with fast developments in modern family life challenging the assumed availability of informal caregivers (Hussein \& Manthorpe, 2005; Bremner et al, 2010). Existing evidence suggests that older people, and their caregivers, usually prefer receiving care in their own homes or in the community rather than in institutional care settings (World Health Organization Europe, 2008; Stern \& Caro, 2004). In Turkey, similar to many countries in the Middle East and neighboring regions, elderly care is considered to be the sole responsibility of family relying on strong traditional social assumptions and embedded responsibilities within the family (Turkey State Planning Organization (DPT), 2007:51). However, the availability of informal caregivers is increasingly questioned with more participation of women in the labor force as well as changes in the family structure and co-residency (Turkey-Analytical Support on the Socio-Economic Impact of Social Protection Reforms [ASSIP], 2009; DPT, 2007), emphasizing the importance of a suitable formal solution for long-term care that is both culturally sensitive and maintains older people's residency in their own homes and communities for as long as possible.

In Turkey, family members, usually daughters or daughters in-laws, are increasingly finding it difficult to balance their informal care needs and other duties resulting, in some situations, to inadequate care for the elderly (DPT, 2007; Yağcioğlu et al, 2010) or high stress levels and mental health issues for caregivers (Alpteker, 2008). Increasingly, older people are left alone at home or cared for by untrained caregivers or, in relatively fewer cases, are placed in institutional or residential care settings (DPT, 2007: 24-31). At the same time, evidence on the cost implications of informal care and its effect on labor market participation and informal caregivers' wellbeing are numerous and should not be ignored (DPT, 2007; Hussein et al, 2009).

As part of the consequences of lack of adequate long-term care and formal care workers, there is potential risk for many older people to be subjected to social isolation, health problems, and emotional and mental dependency leading to poor quality of life (Cavellero et al, 2007; Stanley et al, 2010). Whereas many studies suggest that the integration of older people in social groups is significantly important for both quality of life and wellbeing (Isaac et al, 2009; Molzahn et al, 2009). 
İzmir is a large city, the third most populous city in Turkey, with 12 per cent and 8 per cent of its population over the age of 60 and 65 years respectively. The retirement age for men in Turkey is 60 and for women is 58 years while life expectancy for men is 71.7 years and for women is 76.5 years. In 2010, the prevalence of people aged 60 years or more has increased to 12.3 per cent and those older than 65 years to 8.3 percent (TUIK, 2010). There are clear indications of shortages in long term care provisions in İzmir with over 400 older people on the waiting list for residential care in 2008 (SHCEK, 2008). There are 41 institutional care settings across İzmir (e.g., residential homes, nursing homes, care homes) with a total of 3,331 bed capacity owned and run by the Turkish Social Service and Children Protection Institution (SHCEK), local government, nonprofit and for-profit organizations, with only two senior centers (social clubs for healthy older people, called solidarity centers in Turkey) (SHCEK, 2010). There are no other forms of long-term care provision in Izmir, in particular, no adult day care centers or home care agencies that maintain the care for older people in their own homes or within their immediate community.

\section{Adult Day Care: Opportunities and Challenges}

Over the past few decades changes in social, economic, and medical technology has increased both longevity and the needs for formal long-term care to complement, and in fewer cases substitute, informal care provision (Dupuis, Epp \& Smale, 2004). Communitybased care models aiming to provide both activities of daily living (ADLs) and social needs of care-dependent older people, have started to gain interest in some regions in Turkey (DPT, 2007; Kröger, 2009; SHCEK, 2008). Adult Day Care (ADC) is one of community-based care models that can be more culturally acceptable than residential care in Turkey. The major goal of ADC is to provide formal LTC in a way that is likely to reduce psychosocial problems (such as insecurity, depression, and loneliness), ensuring the maintenance or recovery of older people's ability to perform activities (cognitive, spiritual, and physical) of daily living while promoting independency and autonomy of older people with satisfactory levels of health-related behavior, such as nutrition and exercise (Isaac et al, 2009; Bilotta et al, 2010). Concurrently, ADC helps families keep relatives at home for as long as possible, reducing and delaying the need to consider nursing home or an assisted living facility with considerable social and economic benefits (Alteras, 2007; Cho et al, 2009; Dupuis et al, 2010). ADC is fairly common in many developed countries due to their benefits to elderly people, and their role in developing an alternative to nursing or residential, with further cost-effectiveness (Rogerson \& Emes 2008; Abramson, 2009).

The current provision of ADC in most Turkish regions is very scarce; subsequently families are usually faced with multiple social and financial burdens to substitute such care gaps (Oglak, 2007; Alpteker, 2008). One of the main challenges in establishing ADC in Turkey has been the invisibility of formal caregiving as an employment option combined by a lack of a well-trained workforce who understand and meet the growing needs of older people in non-institutional environments. While there is a lack of trained and qualified formal care workers there is increasingly high unemployment rates, particularly among women even when they have acquired formal education. In Izmir, the unemployment rate is as high as 75 per cent for high school and 43 per cent for university graduates (TUIK, 2009). 
Within such context, there is a great potential in recruiting and training unemployed women to meet the growing demand for formal caregiving. Caregiving with its altruistic and emotional nature may be suitable to Turkish women who may prefer a career that is compatible with their traditional and normative roles. At the same time, ADC service is also an invisible form of care for older people in Turkey, with most informal caregivers unaware of their existence and potential benefits. Overall, the understanding and appreciation of social activities in relation to reducing depression and improving older people's quality of life appears to be limited within the majority of the Turkish society (Nahcivan \& Demirezen, 2005).

From these perspectives, the current project was conceptualized as an innovative way of creating employment and vocational training opportunities and meeting growing needs for care, thus providing further opportunities for labor force participation among informal caregivers. This project could act as a model to be adopted in other areas and regions in Turkey or other countries with similar social constructs.

\section{Participants}

\section{Methods}

There are three data sources: 1) 78 women who participated in the training program; 2) 254 older adults who received care from the trainees during the course of the program; and 3) the Project Management Team (PMT), that consisted of 5 professionals: project coordinator, vice coordinator (Professor in nursing) and 3 trainers (one sociology graduate and two nurses). The sample description of trainees and users is provided in Table1a and $1 \mathrm{~b}$.

Table 1a. Demographic characteristics of the trainees

\begin{tabular}{|c|c|c|}
\hline Age & Number of Trainees & $\%$ \\
\hline $18-24$ & 14 & 17.95 \\
\hline $25-34$ & 38 & 48.82 \\
\hline $35-44$ & 18 & 23.08 \\
\hline $45-55$ & 8 & 10.25 \\
\hline$n=78$ & & 100 \\
\hline \multicolumn{3}{|l|}{ Educational status } \\
\hline High School & 61 & 78.21 \\
\hline University & 17 & 21.79 \\
\hline$n=78$ & & 100 \\
\hline \multicolumn{3}{|l|}{ Marital Status } \\
\hline Married & 47 & 60.25 \\
\hline Single & 31 & 39.75 \\
\hline$n=78$ & & 100 \\
\hline
\end{tabular}


Table 1b: Users' distribution by age and gender

\begin{tabular}{|l|l|l|l|}
\hline Age & Female & Male & Total \\
\hline $55-69$ & 43 & 46 & 89 \\
\hline $70-79$ & 55 & 22 & 77 \\
\hline $80+$ & 82 & 6 & 88 \\
\hline Total & $\mathbf{1 8 0}$ & $\mathbf{7 4}$ & $\mathbf{2 5 4}$ \\
\hline
\end{tabular}

\section{Measures}

The evaluation method was based on a combination of process and outcome evaluation design and consisted of measuring five main elements: 1) application numbers, completion and withdrawal rates of trainees in the initiative; 2) PMT assessment of the impact of the initiative on service users and trainees and; 3) self-assessment of the program by trainees including their own perception of the process of aging and the care sector as employment opportunity; 4) users' (older people) evaluation of the impact of the activities on their wellbeing and their evaluation of the trainees; 5) The successful establishment of ADCs in the region of Izmir (see Chart 1 for details).

We employed a process evaluation design and a post-effect analysis of the impact of the training program on trainees and users. Levels of applications to the training program were measures using overall number of applications, successful interviews and training completion rates. Trainees rated their satisfaction levels with different elements of their training after each session, on a 4-point scale of 'very satisfied', 'satisfied', 'dissatisfied', and 'very dissatisfied'. At the end of the full training course they were asked to provide written feedback on the initiative and offer their reflections on their level of preparation and perceptions of aging.

As part of the assessment process the PMT observed and noted levels of satisfaction of users with the activities and the trainees. These were based on level of satisfaction of users, on a 4-point scale from 'very satisfied' to 'very dissatisfy', with six main elements. First, the observation of older people performing the suggested new activity provided by the trainees; second, if users continued participating until the end of the initiative; third users' feedback (verbally or otherwise) on their experience; fourth, body language and other communicated observations the evaluation team noted; fifth, users' expressed feeling at the time of the activity when requested by the team (angry, happy, etc.); and finally, users' request to repeat the experience/activity again. Users, who received care by the trainees during the program, were asked to provide verbal feedback when possible. 


\section{Chart 1 Training and evaluation process}

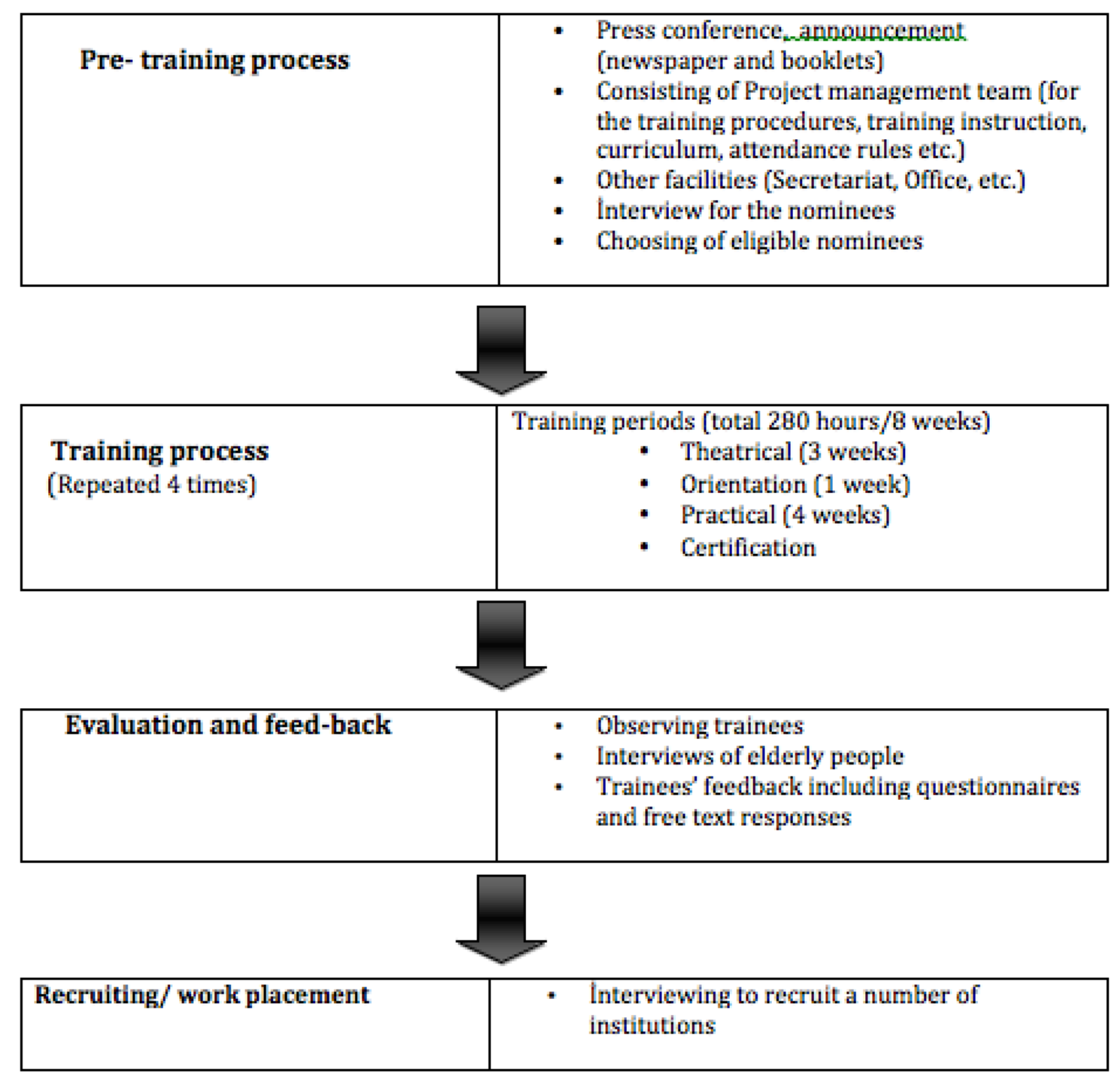

\section{Procedure}

The data were collected through out the course of the program, with application data from the onset of advertising for the training program. Trainees completed their feedback forms after each session before leaving the classroom; feedback sheets were anonymous. After completing all practical sessions with users, trainees provided written feedback in a classroom environment using free-text format. PTM collected and observed users' feedback completing each of their sessions with the trainees to minimize recall bias. The analysis procedures started by describing this new model of training then was followed by an initial evaluation of this program. The description of the training program included details of its structure, curriculum and activities.

\section{Analysis}

Quantitative data on numbers of applications received, successful recruitment and course completion rates are descriptively analyzed along with selected socio-demographic characteristics of trainees. All verbal and written feedback from trainees, service users and the PMT were analyzed thematically by two researchers and discussed further to develop a consensus of main themes. The analysis was guided by the conceptual relationships between different outcomes (trainees', trainers and users' satisfactions) and potential 
influencing factors. We conceptualized those different outcomes to be critically linked to the awareness of formal caregiving as an employment route within the community of Izmir as well as the perception and image of such jobs. Given the scarcity of ADCs to start with and the concentration of caregiving within the informal sphere, we anticipated that trainees may not be willing or motivated to take part in the project. However, this was balanced with the view of a tight labor market opportunity particularly for women in İzmir and the attraction of 'free' training. The model then anticipated that if these forces are balanced, allowing a satisfactory number of women to apply for and complete the program, the continuous employment of those trained in the sector might be questioned due to exogenous factors of awareness, image and perception of the value and importance of formal caregiving.

The analysis also aimed to capture the experience of working with older people in a creative and innovative approach and the impact of trainees' exposure to 'reflective practice' on the wider meaning and value of aging for others and own selves. Similarly, experiencing new forms of services and the way they are delivered, including social care and interactive activities, may provide older people with a new dimension to otherwise, routine daily activities. The evaluation attempts to explore these themes and provide older people with an opportunity to reflect on both the new approach of services as well as the way they were delivered by formal caregivers who may not have a background in nursing for example. Within this framework, there is a possibility that older people may be overwhelmed with several changing factors with difficulties in separating the effect of individual elements on their perceptions and feedback.

\section{Training program description: Educating Caregivers for Employment in Adult Day Care Centres in Izmir (SBAP)}

This project was funded by a grant program designed by the Active Labor Employment Measures Grant Scheme and co-funded by the European Union and Turkish Employment Organization (ISKUR) within the framework of employment opportunities of women and youth. SBAP was one of 101 projects selected amongst 1,500 submitted applications for funding from across Turkey. The project took place from December $1^{\text {st }}$, 2008 and November 30th 2009 (12 months) through a partnership between Buca Municipality and Buca Directorate of Public Education, run under the Social Assistance and Solidarity Foundation of İmir Governorate. Due to the nature of the program and its concurrent evaluation, the evaluation did not require a separate ethical approval. However, participants (both trainees and users) were made aware of the evaluation and its purpose with written consent obtained from trainees while verbal consent from users.

One of the main aims of the formal caregiver training project was to offer a new training opportunity in long-term care, thus addressing two social issues simultaneously; lack of care provision and reducing female unemployment rates. Thus unemployed, but formally educated, women in Izmir were targeted. Specifically, the invitation was for women aged between 18 and 55 years with at least high schooling, who lived in İzmir and were unemployed and registered as job-seekers at the Turkish Employment Organization (ISKUR, 2010). The project's main aim was to offer 80 unemployed women in Izmir such training opportunities of formal caregivers through a vocational training program. SBAP's second goal was to provide some illustrative examples of the structure and activities of ADC with a vision to establish a number of ADCs in the region. Given that there were no 
ADC provisions in Izmir at the time of the project, the project recruited eight already established organizations that provided more traditional LTC to introduce social day care activities with existing residential care users. Participating organizations included nonprofit institutional care centers, residential care homes, nursing home, senior centres, general hospital, İzmir Alzheimer's Foundation, and Balçova Thermal Hotel and Cure Centre.

\section{Recruitment to SBAP}

Trainees' recruitment was through advertisements in local newspaper, displayed in local areas and shops and via the Internet. Special advertisements for workers as well as interested organizations were broadcasted on local TV and radio channels. A public press conference about the aims and training of the project to inform interested institutions to host the ADCs was held. After the interview process, 84 women (out of 274 applicants) were offered the training opportunity and 78 completed the training. Buca Public Education Center processed the registration of candidates in accordance with the requirements of the Ministry of National Education for apprenticeship education management.

Presentations, meetings, and dissemination of the purpose and aims formed an important part of public engagement from the beginning to the end of the project. Because formal caregiving training is a new concept in Turkey, it attracted the interest of local government, nonprofit institutions and for-profit agencies. Efforts to introduce and disseminate the project aims and structure were mainly carried out by explaining the importance and necessity of the program in more than 30 interviews and organizing national and international conference/symposium and meetings.

These sessions have engaged some important stakeholders, including policy makers and directors of existing LTC facilities and business entrepreneurs, who indicated some understanding of the potential for social care, social integration, and socialization for the elderly people and were willing to participate and pioneer training formal caregivers.

\section{SBAP Training structure}

The training process included four main elements: theoretical, practical, evaluation and formal examination and was implemented in a total of 280 hours (120 hours theory and 160 hours practice). Training periods were repeated four sessions for each training group period from March to July 2009. Formal Caregiver education curriculum was constituted of 11 units, under the titles of occupational health and safety, basic care skills, personal care, first-aid, nutrition, medication administration, exercises and physiotherapy, social activity planning, communicational skills and problem solving. Training resources and visual materials were prepared in English and Turkish to provide an effective training process. Because the ADC services and caregiver training are new concepts to Turkey, we invited an expert nurse from Proteion Thuis Elderly Care Institution in The Netherlands, specialized in elderly care and adult day care social activities, for ten days to provide part of the theoretical and practical training.

Theoretical training was provided by six qualified trainers (mainly nurses) for 40 hours a week, which was provided to 20 trainees groups through interactive educational methods in a classroom setting. In addition to lectures and group discussions, pre-clinical practice included role-play and the use of anatomical health models and equipment, these training methods has shown to increase trainees' competency. 
Trainees were required to pass their theoretical examinations before taking part in a 4-weeks practical training in the participating organizations, which were supervised by professional staff and trainers. Feedback and evaluation after each session formed an important element for learning and enhancing the program of education and; also served as a significant element in the evaluation process. Due to the fact that there were no adult day care centers in İzmir, trainees had the chance to practice in other participating care settings including İzmir Alzheimer Association. Trainees practiced a set of newly introduced activities that are likely to form parts of the newly introduced ADC, such as social activities, games and creative work. These were designed by the SBAP team and discussed with professionals working in participating organizations, where times for such activities were agreed. Trainees provided these activities to a range of service users under the supervisions of professionals, such as physicians, nurses and social workers as well as project coordinator, vice coordinator and trainers. Staff, users and trainers' written and verbal feedback on trainees' performance and attitude formed part of the assessment process as well as the evaluation of the project.

\section{SBAP Evaluation Results Applications and trainees progression}

In total, 274 applications were received and 105 of 214 applicants who were invited to interviews were accepted as qualified candidates. Some applications were rejected from the onset due to not meeting eligibility criteria such as gender, education level or being already employed. Some women decided not to take part after the interview due to their misunderstanding of the purpose of training, confusing it with child care training and declining to work with older people. Following the interviews, 84 women who were accepted as trainees underwent training. The high number of applications may have reflected the high unemployment rate in the region, as discussed above, but may also indicate that working in long- term care may be considered a suitable option by many.

During the training period, 6 women withdrew from the course for different reasons; two because their husbands disagreed; three found other jobs and one married and decided to delay her entrance to the labor market. SBAP almost met its target by training 78 trainees, instead of 80 , who successfully completed both theoretical and practical training periods. During the training program two trainees were found incompetent due to unfavorable feedback during their practical session and relatively low grades in their theoretical examinations resulting in a total of 76 women being certified as formal caregivers in ADC settings.

Trainees completing the program were aged between 25 and 44 years with around 18 percent younger than 24 years and 10 percent older than 45 years. Over three quarters of trainees had high school education with a considerable proportion of 22 percent with university education; the majority of women were married.

\section{Project management team's (PMT) assessment}

Overall, the PMT felt that SBAP achieved its aims and provided training opportunities for women who were keen to learn about this area.

"All the trainees were very pleased with the training periods; they think that it was a golden opportunity for them. I am pleased for being a trainer in this Project. I observed that trainees established close relations with us. 
They appreciated that relationship and they believed that this helped them to have a good network." (Trainer, Nurse, 55 ages)

The PMT also felt that the SBAP offered them an opportunity to share their knowledge and influence new recruits to this sector:

"I graduated as a nurse in Germany. Thanks to this Project. I can apply of my experiences and knowledge's in practice training I definitely know ADC from Germany aging policies, however, I did not see this it anywhere in Izmir, before. The good news is that trainees are so excited and motivated to train in this subject. I could easily see this in their eyes". (Trainer, Nurse, 37 ages).

They also observed a positive effect on users participating in the SBAP project:

"We have taken a number of positive feedback from patients, elderly people as well as staff in favor of our trainees. We considered SBAP to be quite a necessary project both elderly people and trainees in our usual fortnightly meetings." (Project Coordinator)

Table 2. Trainees' self-evaluation of different training elements

\begin{tabular}{|c|c|c|}
\hline \multicolumn{2}{|r|}{ ELEMENTS OF TRAINING } & $\begin{array}{c}\text { Satisfied } \\
\text { or very } \\
\text { satisfied } \\
(\%)\end{array}$ \\
\hline \multirow{2}{*}{$\begin{array}{c}\text { TRAINING } \\
92 \%\end{array}$} & Sufficient information on the aim of the training was given & 92 \\
\hline & Sufficient information on the training program was given & 92 \\
\hline \multirow{4}{*}{$\begin{array}{c}\text { TRAINER } \\
\text { 93\% }\end{array}$} & Trainers were expert in their knowledge subject & 95 \\
\hline & Trainers completely utilized the training materials and facilities & 77 \\
\hline & Trainers ensured our active participation & 97 \\
\hline & Trainers had provided a good communication with the trainees & 97 \\
\hline \multirow{9}{*}{$\begin{array}{c}\text { CONTENT OF } \\
\text { THE } \\
\text { TRAINING }\end{array}$} & The content of the training was adequate & 97 \\
\hline & I believe that the training will be helpful in everyday life & 94 \\
\hline & Training increased my skills and experiences & 100 \\
\hline & Activities related to the practice training were performed & 92 \\
\hline & Vocational skill laboratory helped to increase my learning ability and skills & 87 \\
\hline & Schedule of lessons and breaks was convenient & 90 \\
\hline & Visual materials were used to facilitate learning process & 80 \\
\hline & $\begin{array}{l}\text { Classroom scheme was convenient to ensure learning and interactive } \\
\text { participation }\end{array}$ & 80 \\
\hline & Table name tags were convenient in terms of social integration & 98 \\
\hline
\end{tabular}




\section{Trainees'self-evaluation}

Comments and feedback received from trainees at the end of the theoretical and practical sessions indicate a highly successful training period. Trainees' self-evaluation of the different theoretical sessions regarding the trainers, education methods, and content, indicated that more than 90 percent of trainees to be 'very satisfied' with different elements of teaching (see Table 2).

Comments provided by the trainees after the completion of the course were further analyzed thematically to highlight several important elements about their attitudes towards care work as well as their understanding of aging more generally. These revolved around two main themes, the first is the discovery of the meaning of the aging process itself and the other is a reflection and appreciation of the role of formal caregiving as important to both users and workers. These findings fit well with the conceptual framework and can be an indication that the program offered a challenge to certain, possibly stereotypical, views of aging within the Turkish society. With the trainees away from their immediate cultural and kinship circle, they had an opportunity to receive new knowledge and reflect upon it through practice. Similarly, they were able to reflect on the role of formal caregiving through first hand experience. Trainees discussed perceived emotional rewards attached with such work, including the essential value of good communications, and reflected on older people through a new lens of understanding and insight. Many trainees seemed to used their training opportunity to reflect, in many cases for the first time, on the whole concept of aging. Many also connected this newfound understanding to spiritual feelings as illustrated by the following comments from trainees:

"This course made many spiritual contributions for me. I learned that elderly people need affection before anything else."

"This was beyond my imagination. You could have thought elderly people are like children. However, they are not children either, they are very special. This training course which I began with a little unease was so different that it was not only a course for me but a life-long education. My fears have disappeared. Later on the blessings, miraculous words... all with excitement... Now I've discovered the meaning of life."

"Before attending the training, I thought that elderly people do not have any expectation. I witnessed in the course that only the body is aged, but the thoughts and feelings remain young. I saw the real life. I am lucky to have participated in it. I renewed myself. Thanks."

\section{Older people's perception}

Level of satisfaction and perception of 254 older people who experienced the introduction of ADC in Izmir and received care from trainee formal care workers were observed and noted by the PMT. The vast majority of participating users were satisfied or very satisfied with both social care activities (personal care) and social activities (reading; drawing; bingo etc.). Table 3 lists the percentage of users satisfied with different elements of the training process. The very high level of satisfaction may be attributed in part to the novelty of activities, which may have contrasted with the less engaging form of care they usually experience in residential care or hospitals. Overall, the majority of users commented that the presence of social care services in the form of ADC activities and 
caregivers supplemented an important gap in the social care and formal caregiving services.

Table 3: Users' level of satisfaction with personal care and social activities

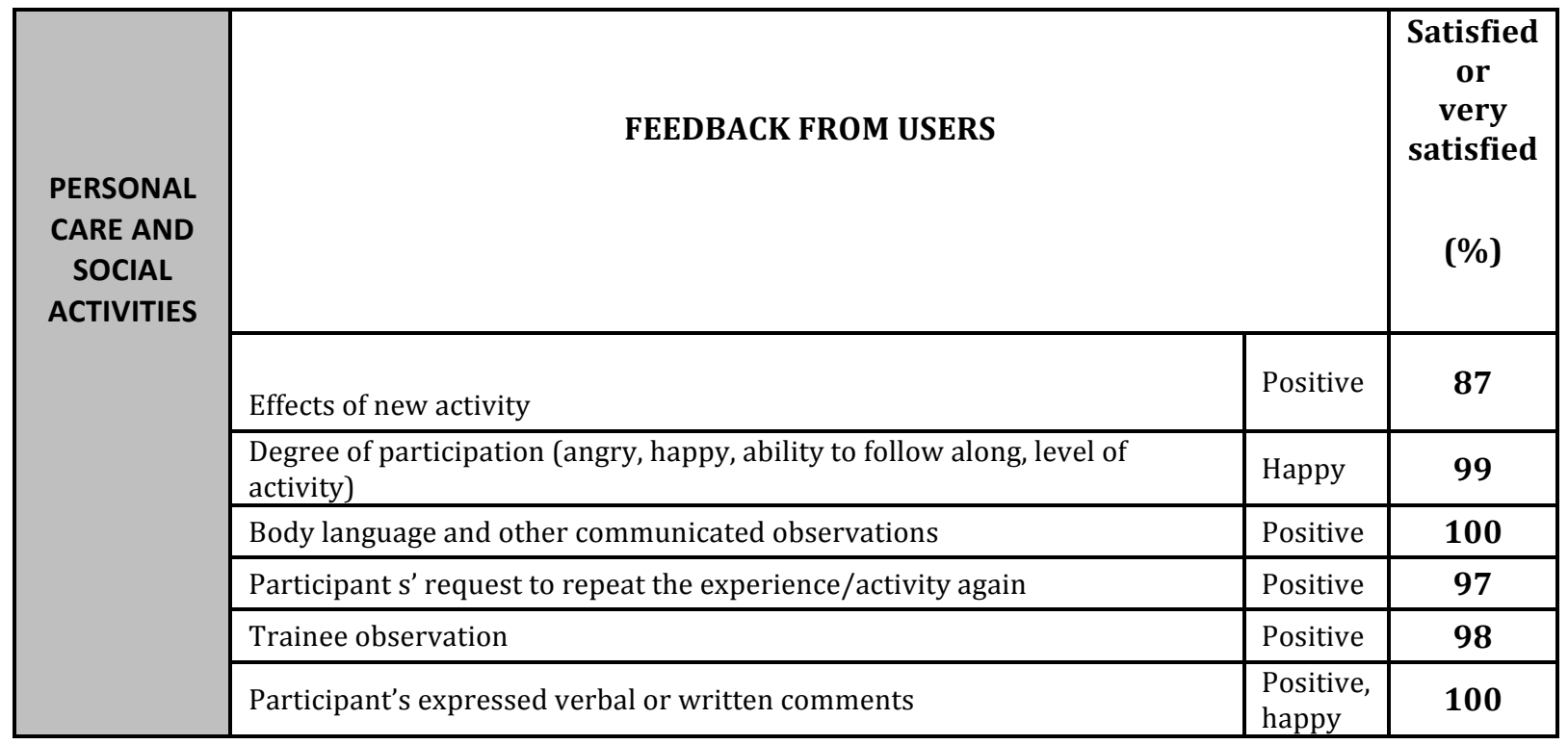

Users highlighted a number of important themes in relation to ADC activities and their experience with the trainees. Overall, users felt that new social activities introduced by the SBAP initiative greatly enhanced their quality of life and in many cases made them feel valuable and 'alive' again.

"It has been a long time since I last played name-city game. At first, I thought that I forgot the names of cities. However, when I began to play the game, it made me quite happy to remember the names. I applauded myself for each correct answer, and I was very glad for playing the game." (Female, 75 years old).

Many also felt capable with a new perception of aging and how to spend their times; and the new concept that 'it is alright to enjoy and have fun!"

"I went down to the garden upon the insistence of trainees, I hadn't gone out for quite a long time. I sang songs, kept times and chatted with my friends. I spent so wonderful a day that I wished to go down and spend times in garden every day." (Female, 83 years old).

"I was quite bored before the activities and the time laid heavy on my hands. When I began to do paintings and puzzles, I felt quite happy like a child, my morale was boosted and wanted them [trainees] to come everyday." (Male, 76 years old).

The engaging activities and involvement older people felt made them feel more valued, which is an important corner in their emotional wellbeing.

"I've come to hospitals for many times. However, for the first time, I felt myself valuable, may God bless them."(Male, 70 years old). 
"How wonderful it is to express my feelings through poems. How wonderful it is to see so respectful workers! How much have I missed reading poems and talking to some so sincere." (Male, 88 years old).

"The trainee helped me to make a frame from card boards. We nicely cut the edges and decorated its surrounding with flowers and ribbons. I did not notice how fast the time passed; in addition, it made me quite happy to see my creativeness." (Female, 80 years old).

Users' comments clearly indicate their strong desire to participate in social activities and social integration demonstrating the importance of special interest, attention, and social interaction. They indicated that prior to such experience they found it difficult to fit into society and felt they were out of place and do not have much value.

\section{Establishing new ADC centers}

Buca Municipality, one of the project partnerships, promised to establish an ADC center upon the completion of the initiative and to employ some of SBAP trainees as part of the process. However, this aim has not been materialized yet mainly due to wider economic issues. On a positive note, upon the very encouraging feedback received, İzmir Provincial Directorate of Social Services established an ADC with a capacity of ten people within the body of Buca Residential Aged Care Center in 2009 and provided employment to two of the trained caregivers. Another trained caregiver was employed in a local not-for-profit residential care home by the end of the SBAP program. It was not possible to follow the employment route and career path of other trained women in SBAP, however, many are likely to be working in the unregulated care market in the region due to the training they received and the continuous demand. Furthermore, some of the for-profit (private) organizations in the region have shown interest in trainees and offered them jobs in elderly care services.

\section{CONCLUSION}

There has been an increasing attention of the labor market opportunities within the long-term care sector in Turkey, with some recent training programs aimed to attract unemployed women to the sector. For example, Bayı and Uysal (2010) report on one of these initiatives which aimed at providing training for a group of unemployed women to work in residential care settings in 2005. Bayik and Uysal focus was on evaluating the training program on workers' knowledge, they concluded that the program was effective with workers' knowledge of care practice improved significantly after the training course. The current evaluation of a more recent project (SBAP, 2009) highlights the multiplicity of benefits from adopting such models not only on trainees' learning care curriculum but also on challenging traditional concepts of aging and introducing a social model of care through adult day care (ADC).

The SBAP project aimed to provide a model that introduces and encourages the establishment of (ADC) as an alternative to and complement of residential and informal care. With potential positive impacts on older people themselves, unemployed women and informal caregivers who struggle to balance their many duties. ADC have the potential to offer older people services that would not exclude them from the community and delay their need for institutional care and nursing homes which is beneficial for their wellbeing 
and is likely to be cost-effective. ADC services represent an alternative to current models of institutional and community-based long-term care providing labor market opportunities to many unemployed women who may find vocational training engaging and rewarding emotionally and economically.

The project evaluation indicated a good public interest in the introduction of ADC and highlighted the potential of positive outcomes for both elderly/ill people and families. Overall the project process was highly regarded in Turkey at the time of the program (Yeni Asir Gazetesi, 2010; Çohaz, 2010). While the initiative did not progress as envisaged by establishing several ADC services and employing all formal trainees in Izmir, nevertheless, it has succeeded in introducing this concept of care and the care sector as a potential labor market. As in many other countries, formal caregiving is not well known as older people rely heavily on informal care from their family and close friends (Faul et al., 2010; WHO Europe, 2008; Jacoby, 2006; Theobald, 2003: 170; Daly, 2001: 37). Additionally, older people have almost no social security benefits in Turkey, which may increase their financial reliance on family members. At the same time, the growing needs for long-term care and the difficulties many informal caregivers face in providing such care present employment opportunities for many. However, due to the lack of awareness and training opportunities for formal caregiving in Turkey, many workers are employed informally by family members and the private sector, usually with very little employment rights or job security (OECD, 2010:15; Turkey-Analytical Support on the Socio-Economic Impact of Social Protection Reforms (ASSIP), 2009; Oglak, 2008). These intersecting elements may pose multiple barriers for caregiving to become a formal and valued labor force, but they also present several opportunities. Long-term care insurance, which has been established in social security system of many developed/developing countries, has slowly started to gain public and policy interest within the Turkish Social Security System. This is regarded as a good development for the improvement of older people's quality of life and social care services (OECD, 2011; Bilotta et al., 2010; Cohen, 2002).

Non-residential care alternatives should be supported, with the focus placed on the affordable community-based social care services that are more culturally acceptable to older people and their families and have the potential to provide solutions to the rapidly increasing care problems of the elderly population in Turkey.

\section{Acknowledgment}

This project was funded by a grant program designed by the Active Labor Employment Measures Grant Scheme and co-funded by the European Union and Turkish Employment Organization (ISKUR) within the framework of employment opportunities of women and youth: the project received a grant of 134,737.00 Euros, lasted 12 months, and took place from December 2008 to November 2009. The views expressed are those of the authors only and do not necessarily represent those of the European Union or Turkish Employment Organization. 


\section{References}

Abramson, M.C. (2009). Who are the Clients? Goal Displacement in an Adult Day Care Center for Elders With Dementia. International Journal of Aging and Human Development, 68(1) 65-92. doi: 10.2190/AG.68.1.d

Alpteker, H. (2008). 65 yaş ve üstü bireylere evde bakım verenlerin yaşadıkları güçlüklerin belirlenmesi. Dissertation. Abant İzet Baysal Universitesi Sağlık Bilimleri Enstitüsü Yüksek Lisans Tezi, Turkey

Alteras, T. (2007). Adult Day Health Care Services: Serving the Chronic Health Needs of Frail Elderly Through Cost-Effective, Non-Institutional Care. Health Management Associates. Retrieved from http://www.caads.org/pdf/pdf/hma_adhc_report_final_2007_07_23.pdf

Bayik, T.A. and Uysal A.(2010). Evaluation of an Elderly Care Training Programme for Women. International Nursing Review, 57,: 240-246

Bilotta, C., Bergamaschini, L., Spreafico, S., \& Vergani, C. (2010). Day care centre attendance and quality of life in depressed older adults living in the community. European Journal of Ageing,7, 29-35. doi: 10.1007/s10433-010-0138-4

Bremner, J., Frost, A., Haub, C., Mather, M., Ringheim, K., \& Zuehlke, E. (2010). World Population Highlights: Key Findings from PRB's 2010 World Population Data Sheet. Population Reference Bureau, 65,2. Retrieved from http:// www.prb.org

Cavellero, P., Morino-Abbele, F., \& Bertocci, B. (2007). The Social Relations of the Elderly. Archives of Gerontology and Geriatrics-Supplement,1, 97-100. doi:10.1016/j.archger.2007.01.014

Cho, S., Zarit, S.H., \& Chiriboga, D.A. (2009). Wives and daughters: Differential risk factors in the nursing home placement of cognitively impaired family members. The Gerontolgist, 49, 57-67. doi: 10.1093/geront/gnp010.

Cohen, M.A. (2002). Benefits of Long-Term Care Insurance: Research Findings. Health Insurance Association of America (HIAA), Washington, DC.

Çohaz, A. (2010). Türkiye'de Yaşlı ve Yaşlılara Sunulan Bakım Hizmetleri, Akademik Geriatri Kongresi, KKTC.

Daly, M. (2001). Care Policies in Western Europe. In: Daly M (ed). Care Work; The Quest For Security. (pp--33-53). International Labour Office. Geneva.

Dupuis, S., Epp, T., \& Smale, B. (2004). Caregivers of Persons with Dementia: Roles, Experiences, Supports and Coping, A Literatüre Review. Murray Alzheimer Research and Education Program (MAREP), University of Waterloo, Retrieved 10 March 2010, from,http://www.marep.uwaterloo.ca/PDF/InTheirOwnVoicesLiteratureReview.pdf

Faul, C.A., Schapmire, T.J., D'Ambrosio, J., Feaster, D., Oak, C.S., \& Farley, A. (2010). Promoting Sustainability in Frontline Home Care Aides: Understanding Factors Affecting Job Retention in the Home Care Workforce. Home Health Care Management and Practice, 22,6,408-416. doi: 10.1177/1084822309348896

Hussein, S., Manthorpe, J. \& Bakilana, A. (2009). The Competing Demands for Women's Labor: the Role of Women in Long-Term Care Provision in the Russian Federation. Working paper prepared for the Russian Demographic Policy Note Team, The World Bank, Washington D.C, London: Social Care Workforce Research Unit, King's College London.

Hussein, S. \& Manthorpe, J. (2005). An International Review of Long Term Care Workforce: Policies and Shortages. Journal of Aging and Social Policy, 17 (4): 75-94. 
Isaac, V., Stewart, R., Artero, S., Ancelin, M.L., \& Ritchie, K. (2009). Social activity and improvement in depressive symptoms in older people: a prospective community cohort study. American Journal Geriatric Psychiatry, 17,8, 688-96. PMID: 19625786

İzmir İşgücü Piyasası Araştırması (2010). İzmir Ekonomi Üniversitesi Yayınları,Yayın No: 46,_Retrieved from http://www_eco.ieu.edu.tr/wpcontent//izmir_isgucu_piyasa_arastirmasi.pdf

Jacoby, D. (2006). Caring about caring labor: An introduction. Politics\&Society, 34,1, 5-9. doi: $10.1177 / 0032329205284753$

Kröger, T. (2009). Care research and disability studies: Nothing in common?. Critical Social Policy, 29,3, 398-420. doi: 10.1177/0261018309105177

Molzahn, E.A., Gallagher, E., \& McNulty, V. (2009). Quality of Life Associated with Adult Day Centers. Journal of Gerontological Nursing, 35,8,37-46. doi:10.3928/0098913420090706-02

Nahcivan, N. \& Demirezen, E. (2005). Depressive symptomatology among Turkish older adults with low incomes in a rural community sample, Journal of Clinical Nursing 14 (10): 1232-1240.

OECD (2010). Gender Brief-OECD Social Policy Division. OECD, Paris. Retrieved September 21, 2010, from http://www.oecd.org/els/social

OECD (2011). "Help Wanted? Providing and Paying for Long-Term Care”, Public Long-term Care Financing Arrangements in OECD Countries. Chapter 7, 213-245. OECD Press. France.

Oglak, S. (2007). Long-Term Home Care Services and Social Care Insurance. Turkish Journal of Geriatrics, 10,2,100-108.

Oglak, S. (2008). Home Care Services and Long-Term Care Insurance. İskenderun Municipality Culture Publishing, No:6. İskenderun-Hatay-Turkey

Rogerson, M., \& Emes, C. (2008). Fostering resilience within an adult day support program, Activities, Adaptation \& Aging, 32,1, 1-18.

Sosyal Hizmetler ve Çocuk Esirgeme Kurumu (SHÇEK). (2008). Yaşlı Hizmet Merkezlerinde Sunulacak Gündüzlü Bakım ile Evde Bakım Hizmetleri Hakkında Yönetmelik. Tarih: 07.08.2008, Sayl: 26960, Retrieved December 26, 2009, from http://www.shcek.gov.tr/yasli-hizmet-merkezlerinde-sunulacak-gunduzlu-bakimile-evde-bakim-hizmetleri-hakkinda-yonetmelik.aspx

Sosyal Hizmetler ve Çocuk Esirgeme Kurumu (SHÇEK). (2010). Yaşlı Bakım hizmetleri, Retrieved October 08, 2010, from http://www.shcek.gov.tr/yasli-bakimhizmetleri.aspx

Stanley, M., Moyle, W., Ballantyne, L., Jaworski, K., Corlis, M., Oxlade, D., Stoll, A., \& Young, B. (2010). 'Nowadays you don't even see your neighbours': loneliness in the everyday lives of older Australians. Health and Social Care in the Community, 18,4, 407-414.

Stern, A.L., \& Caro, F.G. (2004). Consumer Perspectives on Quality in Adult Day Care. Gerontology Institute, McCormack Graduate School of Policy Studies University of Massachusetts, Boston, MA, Retrieved 28, October 2009, from http://www.geront.umb.edu

Theobald, H. (2003). Care for the elderly: welfare system, professionalisation and the question of inequality. International Journal of Sociology and Social Policy, 23, 4-5, 159-185.

Turkey-Analytical Support on the Socio-Economic Impact of Social Protection Reforms (ASSIP). (2009). Pensions, Health and Long-Term Care, Annual National Report 2009. Author: Karadeniz 0; European Commission DG Employment, Social Affairs and 
Equal Opportunities. Retrieved June 20, 2010, from http:// www.socialprotection.eu/.../asisp_ANR09_Turkey.pdf.

Turkey State Planning Organization (DPT). (2007). Türkiye'de Yaşlıların Durumu ve Yaşlanma Ulusal Eylem Planı. Sosyal Sektörler ve Koordinasyon Genel Müdürlügü, Yayın No: 2741. Ankara-Turkey, Retrieved 04 October 2009, from http://ekutup.dpt.gov.tr/nufus/yaslilik/eylempla.pdf/.

Turkish Statistical Institute (TUIK). (2009). Labour Force Statistical 2008, Haber Bülteni, 224. Retrieved from http:// www.tuik.gov.tr.

Turkish Statistical Institute (TUIK). (2010). Province Population Census 2009 data. Retrieved from http:// www tuik.gov.tr

Türkiye İş Kurumu (ISKUR). (2010). Yıllık Faaliyet Raporu 2009, Çalışma ve Sosyal Güvenlik Bakanlığı Türkiye İş Kurumu Genel Müdürlüğü, Yayın No: 354,Ankara-Turkey. Retrieved from http:// www.calisma.gov.tr

World Health Organization Europe. (2008). Home Care in Europe, The Solid Facts. Tarricone R \& Tsouros A.D. (ed), World Health Organization Regional Office for Europe. Copenhagen-Denmark. Retrieved from http:// www. euro.who.int

Yagcıoğlu, R., Küçükgüçlü, Ö., \& Tekin, N. (2010). Yatağa bağımlı yaşlı hasta gereksinimleri hizmet sunucuları ve Türkiye'de hizmet çeşitleri, Turkish Family Physician, 1, 3, 8-19

Yeni Asır Gazetesi, "Yaşlılara evde bakım hizmetini geliştirmeliyiz". In Turkish, Retrieved March 17, 2010 from http:// www.yeniasir.com.tr 